\title{
Asesmen Potensi Inteligensi Pada Anak Usia Dini
}

\author{
Nadhirotul Laily', Ima Fitri Sholichah² \\ nadhirotul.laily@umg.ac.id1, ima_fitri@umg.ac.id² \\ Universitas Muhammadiyah Gresik
}

\begin{abstract}
The development of learning based on the potential for early childhood intelligence is very limited. The purpose of this study is to describe the potential intelligence of early childhood. The method used is a descriptive qualitative approach. 5 students are the subjects in this study. The instruments used were intelligence tests, observation, and documentation. Data analysis in this study is an interactive analysis model. The results showed that 5 students ( 2 boys and 3 girls) had IQ abilities from below average to superior categories. Based on this intelligence assessment, it can be a reference for Early Childhood Education (PAUD) institutions to design a curriculum based on child development and in terms of the potential for intelligence to improve the teaching and learning process. The use of child development-based education can improve children's abilities to support future development.
\end{abstract}

Keywords: Assesment, Intelligence, Early Childhood

\begin{abstract}
Abstrak
Pengembangan pembelajaran berdasarkan potensi inteligensi anak usia dini sangat terbatas Riset ini memiliki tujuan supaya bisa memahami deskripsi potensi inteligensi anak usia dini, yang menggunakan pendekatan kualitatif dengan metode deskriptif. Ada 5 anak yang menjadi subjek pada riset ini. Penggunaan instrumen adalah tes inteligensi, pengamatan dan dokumentasi. Analisis data dalam riset ini yaitu model analisis interaktif. Luaran riset menujukkan jika 5 anak (2 laki-laki dan 3 perempuan) memiliki kemampuan IQ dengan kategori di bawah rata-rata sampai dengan kategori superior. Berdasarkan asesmen inteligensi tersebut dapat menjadi acuan bagi lembaga Pendidikan Anak Usia Dini (PAUD) untuk merancang kurikulum berbasis perkembangan anak dan ditinjau dari potensi inteligensi untuk meningkatkan proses belajar-mengajar. Pemanfaatan pendidikan berbasis perkembangan anak dapat meningkatkan kemampuan anak untuk menunjang perkembangan di masa yang akan datang.
\end{abstract}

Kata Kunci: Asesmen, Inteligensi, Anak Usia Dini.

\section{PENDAHULUAN}

Konsep mengenai perkembangan anak dapat dilihat dari proses perubahan individu menuju kemajuan baik perkembangan secara fisik (sensori-motorik), perkembangan kognitif, perkembangan sosio-emosional, maupun perkembangan moral (Santrock, 2007). Perkembangan anak usia dini (0 sampai 5 tahun) ada dalam tahap pra-operasional. Dalam periode ini, menyelesaikan persoalan melalui cara berpikir yang logis sistematik belum mampu dilakukan oleh anak. Kemampuan anak dalam mengolah informasi dari lingkungan juga belum cukup mampu untuk bisa menghasilkan perubahan yang sesuai. Namun, anak sudah mampu menuntaskan masalah melalui tindakan riil dengan merekayasa benda atau objek yang dituju.

Pendidikan Anak Usia Dini (PAUD) yaitu usaha pembinaan yang ditujukan kepada anak sejak lahir hingga usia 6 (enam) tahun yang dilaksanakan melalui pemberian desain pendidikan untuk membantu tumbuh kembang supaya anak memiliki kesiapan dalam memasuki jenjang pendidikan yang lebih tinggi. Satuan atau program PAUD menurut Permendikbud nomor 137 tahun 2014 adalah layanan PAUD yang dilakukan pada suatu lembaga pendidikan dalam bentuk Taman Kanak-Kanak (TK)/Raudatul Athfal (RA)/Bustanul Athfal (BA), Kelompok Bermain (KB), Taman Penitipan Anak (TPA), dan Satuan PAUD Sejenis (SPS). 


\section{Efektor, Volume 8 Issue 1, 2021, Pages 1 - 8 \\ Nadhirotul Laily, Ima Fitri Sholichah}

PAUD pada prinsipnya adalah proses pendidikan dengan sistem berbasis perkembangan, namun, keadaan pada saat ini menunjukkan bahwa tidak semua sekolah memperhatikan prinsip tersebut. Dalam periode yang seringkali disebut sebagai periode keemasan (golden age), otak berkembang begitu cepat hingga $80 \%$. Periode ini tidak akan terulang kembali. Pemberian stimulus melalui pendidikan yang tepat dapat menunjang tumbuh kembang anak-anak secara optimum dapat menunjang perkembangan di masa yang akan datang (Dewi, 2017b). Stimulus dapat berupa aktivitasaktivitas yang merujuk pada enam komponen perkembangan yaitu aspek fisik (sensori-motorik), aspek kognisi, aspek sosial emosional, aspek bahasa dan aspek nilai agama dan moral serta aspek seni dan kreatifitas.

Zeuny (2021) mengutip dari National Association for the Education of Young Children (NAEYC), salah satu ciri PAUD yang baik adalah memiliki kurikulum yang bisa disesuaikan untuk anak yang lebih cepat belajar, dan juga untuk anak yang memerlukan bantuan lebih untuk belajar. Oleh karena itu, para guru harus bisa memahami jika latar belakang, pengalaman, dan kemampuan setiap anak tidak sama, karena setiap anak memiliki metode belajar yang berbeda. Penting untuk membuat program yang kaya dan praktik yang sesuai dengan perkembangan anak yang dipandang sebagai perkembangan semua dimensi (terutama perkembangan kognisi). Hal ini menimbulkan sejumlah pertanyaan yang bisa diajukan dalam konteks Pendidikan Anak Usia Dini (PAUD), misalnya apa kurikulum yang sesuai dengan perkembangan anak? metode pendidikan dan perkembangan apa yang efektif pada periode tahap perkembangan anak? Bagaimana menilai efisiensi program yang dilakukan? Apa perbedaannya antara anak-anak yang diberi pendidikan program tersebut dengan anak-anak lain? Standar apa yang ada untuk merancang dan menilai pendidikan anak usia dini? (Weicart, 2000).

Pertanyaan mendasar yang harus dijawab oleh sistem pendidikan adalah konsepsi atau pandangan tentang kecerdasan yang harus menjadi dasar penuntun bagi kurikulum dan proses pendidikan. Jawaban atas pertanyaan ini dapat diturunkan dari orientasi pendidikan, sehingga perlu memperhatikan dari perspektif kecerdasan. Pemahaman mengenai kecerdasan yang dimiliki anak dalam konteks belajar merupakan hal yang terpenting dalam pendidikan. Salah satu alternatif untuk mengetahui potensi psikologi anak yaitu dengan melakukan asesmen potensi inteligensi. Alfred Binet mengembangkan konsep kecerdasan yang menunjukkan jika dasar kecerdasan individu terlihat pada Intellegences Quetient (IQ). Merujuk pada tes IQ yang dikembangkannya, Binet memposisikan kecerdasan individu berada pada rentang skala tertentu. Hasil dari tes IQ dapat digunakan untuk menggali dan mengembangkan potensi anak untuk menunjang proses belajar sesuai dengan tahap perkembangan.

Penelitian terdahulu mengenai pengembangan pembelajaran berdasarkan potensi inteligensi anak usia dini sangat terbatas. Hasil pengamatan di lapangan menunjukkan masih ada satuan PAUD yang belum pernah melakukan asesmen potensi inteligensi terhadap anak didiknya dan pembelajaran hanya mendasarkan pada kurikulum, salah satunya adalah Kelompok Bermain "X". Berdasarkan hal tersebut, maka riset ini memiliki tujuan untuk memahami gambaran potensi inteligensi anak usia dini.

\section{METODE PENELITIAN}

Desain penelitian yang digunakan adalah pendekatan kualitatif deskriptif. Pendekatan kualitatif deskriptif bertujuan supaya bisa menjelaskan dan menggambarkan kejadian-kejadian yang ada, baik bersifat alami maupun manipulasi manusia, yang lebih fokus tentang ciri, kualitas, dan hubungan antar aktivitas (Sukmadinata, 2011). Pendekatan kualitatif deskriptif juga tidak menyodorkan perlakuan, rekayasa atau perubahan terhadap variabel yang diteliti, namun menjelaskan suatu kondisi nyata atau 


\section{Efektor, Volume 8 Issue 1, 2021, Pages 1 - 8 \\ Nadhirotul Laily, Ima Fitri Sholichah}

yang apa adanya. Hasil yang diperoleh dari pendekatan kualitatif deskriptif lebih menitikberatkan pada substansi daripada generalisir (Sugiyono, 2009).

Penelitian ini berada di lembaga pendidikan anak usia dini Kelompok Bermain (KB) " $X$ ". Sekolah dalam penelitian ini dipilih secara acak dan telah memperoleh ijin dari sekolah tersebut untuk pemberian asesmen kepada anak. KB " $X$ " memiliki murid sejumlah 14 anak dengan rentang usia antara 3 sampai 5 tahun. Subjek penelitian adalah sumber data yang penting dalam penelitian kualitatif. Proses pemilihan subjek pada penelitian ini menggunakan teknik purposive sampling.

Purposive sampling adalah metode pemilihan sampel yang mengacu pada pertimbagan subjektif peneliti, dimana persyaratan yang didasarkan pada ciri tertentu yang telah ditetapkan peneliti berdasarkan pada tujuan riset sebagai kriteria yang harus dipenuhi sebagai sampel. Karakteristik tersebut adalah sebagai berikut: (1) anak yang menjadi murid aktif di KB "X", (2) orangtua mengijinkan anaknya mengikuti asesmen, dan (3) anak bersedia mengikuti asesmen.

Berdasarkan penentuan karakteristik di atas terdapat 5 subjek dalam penelitian ini yaitu:

1. HRA adalah subjek 1 ,

2. MMH adalah subjek 2,

3. MRB adalah subjek 3,

4. NAK adalah subjek 4 ,

5. KHQ adalah subjek 5.

Penelitian kualitatif ini merujuk pada tahapan-tahapan riset yang memperoleh data kualitatif, seperti: ekspresi atau catatan orang itu sendiri atau periaku mereka yang teramati (Bogdan \& Taylor, 1993). Supaya mendapatkan data yang sesuai dengan tujuan yang ingin diraih, maka pengumpulan data yang digunakan dalam riset ini yaitu Stanford-Binet Intelligence Scale, observasi dan dokumentasi.

Konsep inteligensi Stanford-Binet dikelompokkan menjadi empat tipe penalaran yang masingmasing diwakili oleh beberapa tes. Antara lain: (1) penalaran verbal, (2) penalaran kuantitatif, (3) penalaran visual abstrak, (4) dan memori jangka pendek. Adapaun kriteria kategori inteligensi anak yang digunakan mengacu penggolongan IQ berdasarkan Wechsler (LPSP3 UI, 2012) pada tabel 1 dibawah ini.

Tabel 1. Kategori IQ

\begin{tabular}{ll}
\hline \multicolumn{1}{c}{$I Q$} & \multicolumn{1}{c}{ Kategori } \\
\hline$\geq 130$ & Sangat Superior \\
$120-129$ & Superior \\
$110-119$ & Di atas Rata-rata \\
$90-109$ & Rata-rata \\
$80-89$ & Di bawah Rata-rata \\
$70-79$ & Borderline \\
$\leq 69$ & Intelectual Deficient \\
\hline
\end{tabular}

Sumber: LPSP3 UI, 2012

Tahapan yang digunakan pada riset ini yaitu: (1) memastikan jenis alat tes inteligensi dan membuat pedoman observasi sesuai dengan tujuan penelitian, (2) menentukan subjek penelitian sesuai karakteristik yang telah ditentukan peneliti, (3) melakukan inform concent kepada subjek penelitian, (4). melaksanakan asesmen dan pengumpulan data, (5) menginterpretasi data dan membuat kesimpulan dari hasil interpretasi data tersebut. 


\section{Efektor, Volume 8 Issue 1, 2021, Pages 1 - 8 \\ Nadhirotul Laily, Ima Fitri Sholichah}

Model analisis interaktif dari Miles dan Huberman digunakan untuk teknik analisis data pada riset ini. Terdapat tiga komponen dalam model analisis interaktif yaitu reduksi data, sajian data, dan penarikan kesimpulan atau verifikasi.

\section{HASIL DAN PEMBAHASAN}

Inteligensi seseorang merupakan kemampuan untuk bernalar, merancang, menyelesaikan persoalan, berpikir secara abstrak, memahami ide-ide yang kompleks, belajar dengan cepat dan belajar dari pengalaman. Kemampuan ini tidak hanya pembelajaran dari buku, keterampilan akademik atau kecerdasan dalam mengerjakan tes. Namun, hal ini menunjukkan kemampuan yang lebih luas dan lebih dalam untuk memahami lingkungan serta mencari tahu apa yang harus dilakukan (Gottfredson, 1997; Nisbett \& DiLalla, 2000; Aronson, Blair, Dickens, Flynn, Halpern, et al, 2012)

Hasil asesmen yang dilakukan peneliti terhadap 5 (lima) subjek mengenai gambaran inteligensi anak, bisa dideskripsikan dalam tabel 2 dibawah ini.

Tabel 2. Hasil Asesmen Potensi Inteligensi Anak

\begin{tabular}{|c|c|c|c|c|c|c|c|}
\hline No. & Nama & $\begin{array}{l}\text { Jenis } \\
\text { Kelamin }\end{array}$ & Usia & IQ & Kategori & Kekuatan & $\begin{array}{c}\text { Area } \\
\text { Pengembangan }\end{array}$ \\
\hline 1 & HRA & Perempuan & $\begin{array}{l}4 \\
\text { tahun } \\
3 \\
\text { bulan }\end{array}$ & 113 & $\begin{array}{l}\text { Di atas } \\
\text { Rata- } \\
\text { rata }\end{array}$ & $\begin{array}{l}\text { Percaya diri, aktif, } \\
\text { kemandirian, komunikasi, } \\
\text { daya ingat (informasi } \\
\text { sederhana dan praktikal). }\end{array}$ & $\begin{array}{l}\text { Konsentrasi, } \\
\text { penalaran } \\
\text { angka, dan } \\
\text { kematangan } \\
\text { emosi. }\end{array}$ \\
\hline 2 & MMH & Laki-laki & $\begin{array}{l}3 \\
\text { tahun } \\
11 \\
\text { bulan }\end{array}$ & 107 & $\begin{array}{l}\text { Rata- } \\
\text { rata }\end{array}$ & $\begin{array}{l}\text { Konsentrasi, kemandirian, } \\
\text { keakuratan dan ketepatan. }\end{array}$ & $\begin{array}{l}\text { Daya ingat, } \\
\text { Integrasi visual } \\
\text { motorik. }\end{array}$ \\
\hline 3 & MRB & Laki-laki & $\begin{array}{l}4 \\
\text { tahun } \\
1 \\
\text { bulan }\end{array}$ & 86 & $\begin{array}{l}\text { Di } \\
\text { bawah } \\
\text { Rata- } \\
\text { rata }\end{array}$ & $\begin{array}{l}\text { Kemandirian, keakuratan } \\
\text { dan ketepatan }\end{array}$ & $\begin{array}{l}\text { Integrasi visual } \\
\text { motorik }\end{array}$ \\
\hline 4 & NAK & Perempuan & $\begin{array}{l}4 \\
\text { tahun } \\
10 \\
\text { bulan }\end{array}$ & 83 & $\begin{array}{l}\text { Di } \\
\text { bawah } \\
\text { Rata- } \\
\text { rata }\end{array}$ & Daya ingat dan ketekunan & $\begin{array}{l}\text { Integrasi visual } \\
\text { motorik, } \\
\text { kemandirian, } \\
\text { keakuratan dan } \\
\text { ketepatan. }\end{array}$ \\
\hline 5 & $\mathrm{KHQ}$ & Perempuan & $\begin{array}{l}4 \\
\text { tahun }\end{array}$ & 127 & Superior & $\begin{array}{l}\text { Kecerdasan umum, } \\
\text { komunikasi, daya ingat } \\
\text { (informasi sederhana dan } \\
\text { praktikal) }\end{array}$ & $\begin{array}{l}\text { Konsentrasi, } \\
\text { kematangan } \\
\text { emosi, } \\
\text { kemandirian, } \\
\text { kepercayaan } \\
\text { diri. }\end{array}$ \\
\hline
\end{tabular}

Hasil tes mengenai kemampuan IQ anak dengan partisipan sejumlah 5 anak yang terdiri dari 2 laki-laki dan 3 perempuan menunjukkan distribusi skor IQ yang kurang terlihat antara anak laki-laki dan perempuan. Hal ini disebabkan oleh ukuran sampel dalam penelitian ini yang sangat kecil untuk mendeteksi perbedaan dalam distribusi skor IQ antara anak laki-laki dan perempuan. Oleh sebab itu, riset ini menunjukkan tidak terdapat perbedaan jenis kelamin (laki-laki dan perempuan) dalam hal 


\section{Efektor, Volume 8 Issue 1, 2021, Pages 1 - 8 \\ Nadhirotul Laily, Ima Fitri Sholichah}

inteligensi. Selaras dengan penelitian yang dilakukan oleh Budrina (2017) bahwa pada anak usia dini tidak terdapat perbedaan gender dalam prestasi akademik dan perkembangan intelektual. Anak laki-laki dan perempuan usia sekolah dasar memiliki struktur inteligensi yang berbeda. Anak perempuan memiliki kemampuan mnemonik terstruktur dengan kecenderungan kemampuan verbal, spasial dan perhatian yang terstruktur. Sedangkan anak laki-laki memiliki kemampuan verbal dan mnemonik yang terstruktur, dan kemampuan spasial dan perhatian yang tidak cukup terstruktur.

Anak yang menjadi subjek pada penelitian ini berusia pada rentang 3 sampai 4 tahun. 1 anak berusia 3 tahun sedangkan 4 anak berusia 4 tahun. Perkembangan kognisi berkembang cepat pada anak usia dini (2 sampai 4 tahun). Namun, perkembangan koginitf akan mengalami penurunan pada masa kanak-kanak dan remaja. Perkembangan kognitif ini sangat dipengaruhi oleh pertumbuhan otak bahwa pada usia dini, otak anak berkembang mencapai $80 \%$ dan $20 \%$ sisanya berkembang pada masa kanak-kanak akhir (Papalia \& Feldman, 2009).

Hasil penelitian menunjukkan variasi inteligensi pada kelima anak yaitu 1 anak dengan kategori superior, 1 anak dengan kategori di atas rata-rata, 1 anak dengan kategori rata-rata, dan 2 anak dengan kategori di bawah rata-rata. Anak memiliki skor inteligensi yang berbeda dapat dikarenakan perbedaan baik dalam lingkungan dan warisan genetik (Davies G, Tenesa A, Payton A, Yang J, Harris SE, Liewald D, et al., 2011). Penelian terdahulu menjelaskan jika faktor genetis mempunyai kontribusi yang lebih besar dibandingkan lingkungan dalam pembentukan inteligensi (Galton, 2012). Selain itu Monty dan Fidelis (2006) menyatakan bahwa faktor yang mempengaruhi inteligensi adalah usia, jenis kelamin, ras, budaya, dan asupan nutrisi.

Faktor lingkungan mempengaruhi inteligensi secara negatif. Selama awal kehidupan anak yaitu usia 1 sampai 5 tahun ketika terjadi malnutrisi akan mengakibatkan keterlambatan pertumbuhan fisik, perkembangan motorik, perkembangan kognitif yang menyebabkan penurunan IQ (Der, Batty, \& Deary, 2006; Conklin, Gianaros, Brown, Yao, Hariri, Manuck, et al., 2007; Warsito, Khomsan, Hernawati, \& Anwar, 2012; More, Shivkumar, \& Gangane, 2013). Selain itu, kualitas interaksi ibu dan anak sangat menentukan perkembangan inteligensi pada masa bayi dan anak usia dini (Black, Devereux, \& Salvanes, 2010).

Faktor sosial ekonomi juga dapat mempengaruhi inteligensi seseorang. Perbedaan IQ antara anak-anak pada sosial ekonomi menengah ke atas dan anak-anak pada sosial ekonomi menengah ke bawah memiliki perbedaan sekitar 12 poin (Gottfredson, 1997). Faktor sosial lainnya yang mempengaruhi inteligensi anak, salah satunya adalah sekolah. Sekolah adalah salah satu lokasi bagi anak untuk membentuk dan mengembangan fungsi kognisinya. Sekolah tidak hanya menyebarkan informasi tetapi juga mengembangan keterampilan intelektual dan sikap yang mempengaruhi ineteligensi anak. Selain itu, kualitas pengajaran di sekolah dan pengalaman guru berpengaruh cukup besar terhadap IQ (Ceci, 1991).

Salah satu ciri PAUD yang baik yaitu memiliki kurikulum yang berbasis perkembangan anak, terutama perkembangan kognitif. Perkembangan kognisi anak-anak dapat ditinjau dengan metode dimana anak-anak mengetahui dan menafsirkan hubungan antara hal-hal dan peristiwa di lingkungan mereka (Lay-Dopyera \& Dopyera, 1994). Hal yang harus diperhatikan yaitu pada pembelajaran aktif, bahasa, pengalaman, klasifikasi, pengurutan, angka, dan hubungan spasial-temporal (Giles, 2005). Selain perkembangan kognitif, perkembangan memori pada anak usia dini mengarah pada tingkat kemampuan yang sangat penting dalam pendidikan awal dan hanya melalui perkembangan inilah 


\section{Efektor, Volume 8 Issue 1, 2021, Pages 1 - 8 \\ Nadhirotul Laily, Ima Fitri Sholichah}

kemampuan observasi dan persepsi yang akan menimbulkan perkembangan pada dimensi pemecahan masalah dan pemikiran.

Pada dasarnya, menciptakan masalah bagi anak-anak perlu dilakukan secara teratur dan bukan hanya memberi mereka solusi, melainkan memberi mereka waktu yang cukup untuk mengeksplorasi sendiri terhadap masalah tersebut. Hal ini didasarkan pada pembentukan konsep dasar dalam pikiran anak-anak sangat penting untuk memahami dunia, di mana kemampuan observasi dan klasifikasi bergantung pada transisi dari argumentasi yang bergantung pada konsep ke argumentasi logis, maka hal penting untuk memperhatikan perkembangan kognitif. Menggunakan indra dengan benar adalah dasar untuk pengetahuan apa pun, dan anak-anak belajar banyak hal melalui indra. Peraturan Menteri Pendidikan dan Kebudayaan Republik Indonesia Nomor 137 Tahun 2014 tentang Standar Nasional Pendidikan Anak Usia Dini dinyatakan bahwa standar kemampuan problem solving untuk anak usia 4-5 tahun meliputi 1) mengenal benda berdasarkan fungsi, 2) menggunakan bendabenda sebagai permainan simbolik, 3) mengenal konsep sederhana dalam kehidupan sehari-hari, 4) mengetahui konsep banyak dan sedikit, 5) mengkreasikan sesuatu sesuai dengan idenya sendiri yang terkait dengan berbagai pemecahan masalah, 6) mengamati benda dan gejala dengan rasa ingin tahu, 5) mengenal pola kegiatan dan menyadari pentingnya waktu, 8) memahami posisi/kedudukan dalam keluarga, ruang, lingkungan sosial. Dengan demikian, lebih banyak keragaman pengalaman anak menuntun mereka untuk memperoleh dasar yang lebih luas untuk penilaian dan kepercayaan mereka tentang dunia.

Peraturan Menteri Pendidikan dan Kebudayaan Republik Indonesia Nomor 137 Tahun 2014, tentang Standar Nasional Pendidikan Anak Usia Dini salah satunya ialah aspek perkembangan kognitif yang harus dikembangkan meliputi: 1) belajar dan pemecahan masalah; 2) berpikir logis; dan 3) berpikir simbolik, dalam lingkup berpikir logis terbagi lagi mencakup berbagai perbedaan, klasifikasi, pola, berinisiatif, berencana, dan mengenal sebab-akibat. Pemberian kesempatan yang optimal dan sesuai untuk pengembangan berbagai kemampuan anak akan menghasilkan pemahaman yang lebih dalam, meningkatkan kemampuan penerapan konsep, kemampuan mengeksplorasi, menemukan pembelajaran, dan kreativitas. Melakukan kegiatan berfikir akan membantu anak menyadari urutan angka dan meningkatkan kemampuan soal pemecahan. Oleh karena itu, merancang kurikulum berbasis perkembangan anak dan ditinjau dari potensi inteligensi memberikan kemungkinan kepada guru untuk meningkatkan proses belajar-mengajar. Maka disarankan untuk mempertimbangkan semua aspek kecerdasan dan memperhatikan kecerdasan yang menonjol pada setiap anak untuk pembelajaran yang lebih baik. Untuk itu tugas dan tanggungjawab guru pada proses pelaksanaan dan pencapaian tujuan pendidikan merupakan suatu hal yang sangat penting (Hasanah \& Laily, 2020). Pada analisis akhir dapat disimpulkan bahwa pemanfaatan pendidikan berbasis perkembangan anak dapat meningkatkan inteligensi anak, hal ini membantu anak tumbuh dan berkembang secara maksimal untuk menunjang perkembangan di masa yang akan datang.

\section{SIMPULAN}

Hasil penelitian menggambarkan potensi inteligensi pada anak usia dini (3 sampai 4 tahun). Kategori inteligensi anak yaitu 1 anak kategori Superior, 1 anak kategori Diatas rata-rata, 1 anak kategori Rata-rata, dan 2 anak kategori Dibawah rata-rata. Variasi kategori inteligensi pada subjek penelitian dipengaruhi oleh beberapa faktor, yaitu warisan genetik, lingkungan, usia, jenis kelamin, sosial ekonomi, dan peran sekolah. Implikasi dari hasil penelitian ini diharapkan bagi lembaga Pendidikan Anak Usia Dini (PAUD) khususnya para guru, mampu menggunakan hasil asesmen 


\section{Efektor, Volume 8 Issue 1, 2021, Pages 1 - 8 \\ Nadhirotul Laily, Ima Fitri Sholichah}

inteligensi anak sebagai salah satu acuan dalam menerapkan pembelajaran terhadap anak usia dini.

Para peneliti berikutnya diharapkan menggunakan subjek penelitian yang lebih banyak.

\section{DAFTAR RUJUKAN}

Black, S.E., Devereux, P.J., \& Salvanes, K.G. (2010). Small family, smart family. Family size and the IQ scores of young men?. J Hum Res. 45, 33-58. https://doi.org/10.3386/w13336

Bogdan, R., \& Taylor, S. J. (1993). Kualitatif; Dasar-dasar penelitian. Surabaya: Usaha Nasional.

Budrina, E. G. (2017). Gender Characteristics of Intelligence and Academic Achievement of Younger School Children. Procedia-Social and Behavioral Sciences, 237, 1390-1397. https://doi.org/10.1016/j.sbspro.2017.02.201

Ceci, S.J. (1991). How much does schooling influence general intelligence and its cognitive components. A reassessment of the evidence?.Dev Psychol, 27, 703-22. https://doi.org/10.1037/0012-1649.27.5.703

Conklin, S.M., Gianaros, P.J, Brown, S.M., Yao, J.K., Hariri, A.R., Manuck, S.B., et al. (2007). Longchain omega-3 fatty acid intake is associated positively with corticolimbic gray matter volume in healthy adults. Neurosci Lett, 421, 209-12.

Davies, G., Tenesa, A., Payton, A., Yang, J., Harris, S.E., Liewald, D., et al. (2011). Genome-wide association studies establish that human intelligence is highly heritable and polygenic. Mol Psychiatry, 16, 996-1005.

Der, G., Batty, G.D., Deary, I.J. (2006). Effect of breast feeding on intelligence in children: Prospective study, sibling pairs analysis, and meta-analysis. BMJ, 333(7575):945.

Dewi, Y. A. S. (2017b). Metode Pembelajaran Guru Etnis Jawa- Madura Dalam Pengembangan Bahasa Siswa RA di Kabupaten Pasuruan. Seling, 3(2), 94-106.

DiLalla, L.F. (2012). Development of intelligence: Current research and theories. J Sch Psychol, 38, 3-7.

Enung, F. (2006). Psikologi perkembangan: perkembangan peserta didik. Bandung: CV Pustaka Setia.

Galton, F. (2012). The history of twins, as a criterion of the relative powers of nature and nurture $(1,2)$ Int J Epidemiol, 41, 905-911.

Giles, B. (2005). Developmental psychology. Rochester: Grange Books.

Gottfredson, L.S. (1997). Mainstream science on intelligence: An editorial with 52 signatories, history, and bibliography. Intelligence, 24, 13-23.

Hasanah, N., \& Laily, N. (2020). Self-Efficacy dan Kepuasan Kerja pada Guru Taman Kanak-Kanak (TK). Efektor, 7(1), 80-89. https://doi.org/10.29407/e.v7i1.14398

Lay-Dopyera, M., \& Dopyera, J. (1993). Becoming a teacher of young children. New York: McGraw-Hill College. 


\section{Efektor, Volume 8 Issue 1, 2021, Pages 1 - 8 \\ Nadhirotul Laily, Ima Fitri Sholichah}

LPSP3 UI. (2012). Manual dan Norma Intelligenz Struktur Test (IST). Depok: Lembaga Pengembangan Sarana Pengukuran dan Pendidikan Psikologi (LPSP3), Fakultas Psikologi Universitas Indonesia.

Martini, J. (2006). Perkembangan Pengembangan Anak Usia Taman Kanak-Kanak: pedoman bagi orang tua dan guru. Jakarta: PT Grasindo.

Monty, P., \& Fidelis. (2003). Mendidikan Kecerdasan, Pedoman Bagi Orang Tua Dan Guru Dalam Mendidik Anak Cerdas. Jakarta: Pustaka Popular Obor.

More, S., Shivkumar, V.B., Gangane, N., \& Shende, S. (2013). Effects of iron deficiency on cognitive function in school going adolescent females in rural area of central India. Anemia, 819136.

Nisbett, R.E., Aronson, J., Blair, C., Dickens, W., Flynn, J., Halpern, D.F, et al. (1012). Intelligence: New findings and theoretical developments. Am Psychol, 67, 130-59.

Papalia, D. E., Old s, S. W., \& Feldman, R. D. (2009). Human Development Perkembangan Manusia. Jakarta: Salemba Humanika.

Peraturan Menteri Pendidikan dan Kebudayaan Republik Indonesia Nomor 137 Tahun 2014 Tentang Standar Nasional Pendidikan Anak Usia Dini.

Raden, C.P. (1999). Perkembangan Intelegensi Anak. Bandung: Angkasa,

Santrock, J.W. (2007). Perkembangan Anak. Jilid 1 Edisi kesebelas. Jakarta: PT. Erlangga.

Sugiyono. (2009) Metode Penelitian Kuantitatif, Kualitatif dan R\&D. Bandung: Alfabeta.

Sukmadinata, N.S. (2011). Metode Penelitian Pendidikan. Bandung: Remaja Rosadakarya.

Warsito, O., Khomsan, A., Hernawati, N., \& Anwar, F. (2012). Relationship between nutritional status, psychosocial stimulation, and cognitive development in preschool children in Indonesia. Nutr Res Pract, 6, 451-457.

Weikart, D. (2000). Early childhood education: Need and opportunity. Paris: Unesco.

Zeuny, F. (2021). Mengapa PAUD Penting Bagi Perkembangan Anak? https://pauddikmasdiy.kemdikbud.go.id/artikel/mengapa-paud-penting-bagi-perkembangananak/\#: :text=Tujuan\%20utamanya\%20adalah\%20untuk\%20membentuk,mengarungi\%20kehid upan\%20setelah\%20dewasa\%20kelak. Diakses pada tanggal 24 April 2021. 